\title{
Note
}

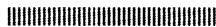

\section{Changes of Indoor Aerosol Characteristics and Their Associated Variation on the Dose Conversion Factor Due to Radon Progeny Inhalation ${ }^{\dagger}$}

\author{
Shinji Tokonami, Takao Matsuzawa*, Tetsuo Ishikawa, \\ Takeshi IIMOTO**, Hidenori YonEHARA and Yuji YAMADA \\ National Institute of Radiological Sciences \\ 4-9-1 Anagawa, Inage-ku, Chiba-shi, Chiba Pref. 263-8555, Japan \\ * Ibaraki National College of Technology \\ 866 Nakane, Hitachinaka-shi, Ibaraki Pref. 312-8508, Japan \\ ** Research Center for Nuclear Science and Technology, the University of Tokyo \\ 2-11-16 Yayoi, Bunkyo-ku, Tokyo 113-0032, Japan \\ Received January 17, 2003
}

\begin{abstract}
Since the dose conversion factor (hereafter called DCF) due to radon progeny inhalation is strongly dominated by aerosol characteristics in the environment, it is important to understand the air quality for accurate dose assessment. Thus temporal variations on aerosol concentration, its particle size and its related airborne radioactivities were continuously measured in an actual indoor environment with a relatively high radon concentration. The following human activities were added during the observation period:airconditioning, removal of aerosol with an air cleaner and ventilation. DCFs based on these activities were evaluated with the latest ICRP respiratory tract model and were compared among them. Consequently, the present study has shown that operation of air cleaner enhanced the DCF critically because the unattached fraction increased significantly due to removal of aerosols.
\end{abstract}

Key Words : dose conversion factor, radon progeny, aerosol characteristics, dose assessment, particle size distribution, ICRP respiratory tract model, unattached fraction, activity median diameter

\section{Introduction}

It is well known that radon progeny inhalation makes a major contribution to public exposure

\footnotetext{
†室内エアロゾルの性状変化とそれに関連したラ ドン娘核種吸入に基づく線量換算係数の変動。 床次畺司, 松沢孝男 *, 石川徹夫, 飯本武志 $* *$, 米原英典, 山田裕司: 放射線医学総合研究所 263-8555 千葉県千葉市稲毛区穴川 4-9-1, * 茨城工業高等専門学校 $312-8508$ 茨城県ひ たちなか市中根 $866, * *$ 東京大学原子力研究総 合センター 113-0032 東京都文京区弥生 2-11-16。
}

from natural radiation sources ${ }^{1)}$. The dose might occasionally exceed the dose limit easily. In general, there are two following exposure processes: external exposure from terrestrial gamma and cosmic radiations, and internal exposure from radionuclides inhaled. In particular, the process of internal exposure is so complicated that many problems remain unsolved. Conventionally, atmospheric radon progeny are classified into two categories: unattached and attached fractions. After radon decays, the progeny of solid particles are 
formed. They are called ultrafine progeny (unattached progeny). Some of them attach to ambient aerosols under the physical law. Radon progeny that attach to ambient aerosols are called attached progeny. The attachment process is strongly dominated by characteristics of ambient aerosols. The particle size distribution of ambient aerosols is also closely related to environmental conditions. Since deposition rates/quantities/distributions of radon progeny in the respiratory tract after their inhalation are dependent upon the particle size and significantly influence the dose, the information on particle size distribution of radon progeny in air is indispensable for accurate dose assessment.

The ICRP has developed a more detailed lung model to calculate the effective dose for exposure to airborne radionuclides ${ }^{2}$. However, it is still a simplification of actual respiratory anatomy and physiological behavior. This model cannot yet be applied to radon and its progeny because the estimates are not consistent with results of risk derived from epidemiological studies. The difficulties include the measurement and specification of aerosol characteristics, including particle size and unattached fraction. However, this model can be used to assess the influence of biological and aerosol parameters and to characterize the uncertainties in estimates of the human lung dose $\mathrm{e}^{3)-5)}$. From such a point of view, it is important to understand aerosol characteristics in the environment. In the present study, therefore, temporal variations on an aerosol number concentration, its particle size and related airborne radioactivities were continuously measured in an actual indoor environment with a relatively high radon concentration. The following human activities were added during the observation period : air-conditioning, venti- lation and removal of aerosol with an air cleaner. Dose conversion factors (DCF) based on these activities were evaluated with the ICRP respiratory tract model and were relatively compared among them. Changes of environmental parameters were investigated and subsequently those of DCF were discussed.

It is expected that this pilot study will reveal the DCF widely changes with the environmental condition and make us find out effective solutions for dose mitigations.

\section{Materials and Methods}

The continuous measurement was carried out in a computer room at a college in Ibaraki prefecture. It last for two days: August 12th through 14th, 1998. The volume and whole surface area are about $400 \mathrm{~m}^{3}$ and $280 \mathrm{~m}^{2}$, respectively. The room can accommodate 50 desktop computers. The wall is made of gypsum board. The wall surface area is estimated to be $130 \mathrm{~m}^{2}$. For cable communication among those computers, there is a small space beneath the floor. An air-conditioner and a ventilator are mounted in the ceiling and can work separately. Attention was paid to environmental conditions during the observation period so as not to affect them by our activities. Table 1 shows the environmental conditions scheduled during the observation period. The following parameters for dose assessment and measurement techniques /devices are assigned to the present work :

(1) Radon concentration : passive measurement with a pulse-type ionization chamber (commercially AlphaGUARD ${ }^{\mathrm{i}}$ )

(2) Individual radon progeny concentration: alpha spectroscopic method with fiberglass

i Genitron Instruments GmbH, Heerstraße 149, D-60488 Frankfurt/Main, Germany. 
Table 1 Environmental conditions scheduled during the observation period

\begin{tabular}{ccc}
\hline Phase & Mode & Duration \\
\hline I & A/C ON, VENT OFF & $8 / 11 / 9811: 00 \sim 8 / 12 / 9818: 00$ \\
II & A/C OFF, VENT OFF & $8 / 12 / 9818: 00 \sim 8 / 13 / 9813: 00$ \\
III & A/C ON, VENT ON & $8 / 13 / 9813: 00 \sim 8 / 13 / 9818: 30$ \\
IV & Air Cleaner only ON & $8 / 13 / 9818: 30 \sim 8 / 14 / 9812: 30$ \\
\hline
\end{tabular}

filters (Whatman $\mathrm{GF} / \mathrm{F}$ ii) for whole progeny and 400-mesh metal wire screens ${ }^{\text {iii }}$ for unattached progeny sampling

(3) Equilibrium equivalent radon concentration (hereafter called EERC) : continuous Working Level monitor (commercially RADON WL METER ${ }^{\text {iv }}$ )

(4) Particle size distribution: condensation nuclei counterv with diffusion battery

(5) Temperature, relative humidity and air pressure

The AlphaGUARD is set to the diffusion mode with a 60-min time interval. For whole radon progeny, an alpha spectroscopic measurement of $10 \mathrm{~min}$ is repeated four times after taking a 5-min grab sample. Their individual concentrations are determined by those counting data ${ }^{6)}$. For unattached progeny measurements, a single wire screen technique is used in the present work. Note that unattached radon progeny are considered as a single type for convenience. The diffusion coefficient is assigned to be $0.065 \mathrm{~cm}^{2} \mathrm{~s}^{-1}{ }^{7}$ ). In terms of the continuous Working Level

ii Whatman International Ltd., Maidstone, England.

iii TETKO Inc., 420 Saw Mill River Road, Elmsford, NY 10523, USA.

iv Thomson \& Nielsen Electronics Inc., Ottawa, Canada.

v TSI Inc., 500 Cardigan Road, St. Paul, MN 55164, USA.

vi Fuso Rikaseihin, Kyoto, Japan. monitor, the EERC is given every $60 \mathrm{~min}$. Although the measurement principle is quite simple, attention must be paid to understanding of their readings because actual concentrations are indicated with some time delay ${ }^{8)}$. For the particle size distribution, a continuous measurement method is applicable. A full description of this device is given by Yamada et $\mathrm{al}^{9)}$. Those three meteorological parameters are continuously measured as well as the radon concentration with the AlphaGUARD.

\section{Results and Discussion}

The ventilation rate was measured by the static decay of $\mathrm{CO}_{2}$ using a digital $\mathrm{CO}_{2}$ monitor Model CD-602 Avi in the room and was found to be the natural ventilation rate of $1.1 \times 10^{-5} \mathrm{~s}^{-1}$ $\left(0.04 \mathrm{~h}^{-1}\right)$ and mechanical one of $3.1 \times 10^{-4} \mathrm{~s}^{-1}$ $\left(1.1 \mathrm{~h}^{-1}\right)$ on the highest mode, respectively. Fig.1 illustrates temporal variations of radon, EERC, temperature, relative humidity, air pressure, and particle size distribution of ambient aerosols (number concentration, geometric mean diameter:GMD and geometric standard deviation: GSD). The weather scarcely changed throughout the entire observation period.

As shown in our previous studies of a high radon level in that room, the average radon concentration was around $150 \mathrm{~Bq} \mathrm{~m}^{-3}$ when no human activities were added(Phase II). The radon concentration was much higher than the annual average indoor radon concentration in 


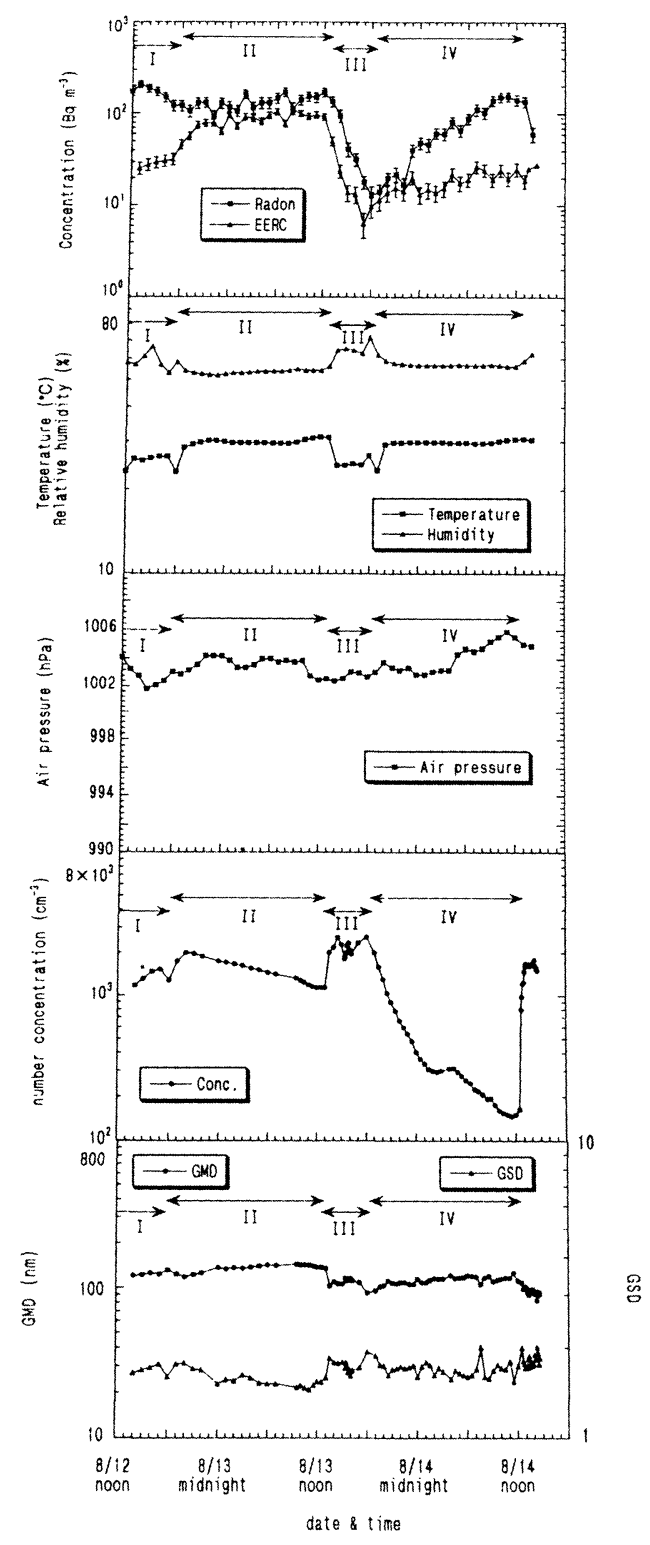

Fig.1 Temporal variations of radon, EERC, temperature, relative humidity, air pressure and particle size distribution of ambient aerosols (number concentration, geometric mean diameter:GMD and geometric standard deviation:GSD). Phase I :single use of air-conditioner. Phase II : no human activities. Phase III : simultaneous operation of air-conditioner and ventilator. Phase IV : single use of air cleaner.
Japan (15.5 Bq m $\left.{ }^{-3}\right){ }^{10)}$. A gamma spectrometry has revealed high ${ }^{226} \mathrm{Ra}$ contents $\left(360 \mathrm{~Bq} \mathrm{~kg}^{-1}\right.$ ) in the gypsum board as wall material. Although some efforts have been made so as to specify a pathway of radon entry using radon exhalation rate measurements on some areas in the room ${ }^{11)}{ }^{12)}$, they have not yet been successful. In fact, the radon exhalation rate was approximately estimated to be $6.0 \times 10^{-3} \mathrm{~Bq} \mathrm{~m}^{-2}$ $\mathrm{s}^{-1}$ as the wall surface area of $130 \mathrm{~m}^{2}$ if the radon comes from the whole wall. Since the actual exhalation rate was $3.0 \times 10^{-5} \mathrm{~Bq} \mathrm{~m}^{-2} \mathrm{~s}^{-1}$, however, a local radon exhalation from a specific area could be expected. Further surveys are required for the identification of the radon source in the room.

A single use of the air-conditioner (Phase I ) did not change the indoor radon concentration but $\mathrm{EERC}^{13)}$. In terms of the particle size distribution of ambient aerosols, it was almost constant throughout Phase I and II. When the air-conditioner and ventilator were simultaneously working(Phase III), on the other hand, the open air reduced both radioactivity concentrations down to the outdoor level. The introduction of the outdoor air enhanced the aerosol number concentration although the GMD became small. The GSD on Phase III was somewhat larger than those on other phases. After two functions stopped, subsequently, the air cleaner installed with a HEPA filter (filtration system) was operated overnight (Phase IV) at the highest flow rate $\left(1.5 \mathrm{~m}^{3} \mathrm{~min}^{-1}\right)$. The radon concentration level gradually recovered up to the original one, whereas the EERC slightly changed with the continuous WL monitor. Although the aerosol number concentration went down to around $1.5 \times 10^{8} \mathrm{~m}^{-3}$ $\left(150 \mathrm{~cm}^{-3}\right)$, the GMD and GSD scarcely changed in comparison with those under other 
Table 2 Results of individual radon progeny concentrations and EERC using an alpha spectrometry

\begin{tabular}{|c|c|c|c|c|c|}
\hline Meas. ID & ${ }^{218} \mathrm{Po}\left(\mathrm{Bq} \mathrm{m}^{-3}\right)$ & ${ }^{214} \mathrm{~Pb}\left(\mathrm{~Bq} \mathrm{~m} \mathrm{~m}^{-3}\right)$ & $\left.{ }^{214} \mathrm{Bi}(\mathrm{Bq} \mathrm{m})^{-3}\right)$ & $\operatorname{EERC}\left(\mathrm{Bq} \mathrm{m}^{-3}\right)$ & Remarks \\
\hline $98081214 \mathrm{~T}$ & $84.8 \pm 8.6$ & $41.2 \pm 11.6$ & $34.7 \pm 5.8$ & $42.5 \pm 6.3$ & Phase I, Total \\
\hline $98081215 \mathrm{~T}$ & $84.4 \pm 4.3$ & $30.3 \pm 2.5$ & $20.7 \pm 1.8$ & $31.8 \pm 1.5$ & Phase I, Total \\
\hline $98081215 U$ & $53.3 \pm 7.4$ & $-4.5 \pm 3.1$ & $2.9 \pm 1.6$ & $4.4 \pm 1.8$ & Phase I, Unattached \\
\hline $98081216 \mathrm{~T}$ & $69.5 \pm 4.0$ & $24.9 \pm 2.4$ & $22.7 \pm 1.8$ & $28.3 \pm 1.4$ & Phase I, Total \\
\hline $98081217 \mathrm{~T}$ & $67.2 \pm 3.6$ & $27.6 \pm 2.0$ & $19.6 \pm 1.5$ & $28.2 \pm 1.2$ & Phase I, Total \\
\hline $98081217 \mathrm{U}$ & $18.5 \pm 4.4$ & $1.5 \pm 2.8$ & $1.4 \pm 1.3$ & $3.2 \pm 1.5$ & Phase I, Unattached \\
\hline $98081309 \mathrm{~T}$ & $126.6 \pm 5.6$ & $74.9 \pm 4.3$ & $83.8 \pm 3.3$ & $82.3 \pm 2.5$ & Phase II, Total \\
\hline $98081309 \mathrm{U}$ & $46.7 \pm 6.7$ & $-0.2 \pm 4.1$ & $4.6 \pm 2.1$ & $6.5 \pm 2.3$ & Phase II, Unattached \\
\hline $98081310 \mathrm{~T}$ & $127.3 \pm 5.6$ & $82.6 \pm 4.3$ & $81.0 \pm 3.3$ & $85.2 \pm 2.6$ & Phase II, Total \\
\hline $98081311 \mathrm{~T}$ & $122.6 \pm 6.7$ & $79.7 \pm 4.5$ & $79.7 \pm 3.6$ & $82.7 \pm 2.7$ & Phase II, Total \\
\hline $98081311 U$ & $62.6 \pm 7.8$ & $0.7 \pm 4.1$ & $2.6 \pm 1.8$ & $7.8 \pm 2.3$ & Phase II, Unattached \\
\hline $98081312 \mathrm{~T}$ & $120.1 \pm 5.4$ & $75.4 \pm 4.2$ & $75.2 \pm 3.1$ & $78.6 \pm 2.5$ & Phase II, Total \\
\hline $98081312 \mathrm{U}$ & $53.1 \pm 7.3$ & $7.0 \pm 4.9$ & $2.9 \pm 2.2$ & $10.1 \pm 2.7$ & Phase II, Unattached \\
\hline $98081314 \mathrm{~T}$ & $18.1 \pm 2.1$ & $7.6 \pm 1.4$ & $8.6 \pm 1.0$ & $9.0 \pm 0.8$ & Phase III, Total \\
\hline $98081314 \mathrm{U}$ & $4.4 \pm 2.1$ & $0.0 \pm 2.3$ & $2.0 \pm 1.3$ & $1.2 \pm 1.3$ & Phase III, Unattached \\
\hline $98081315 \mathrm{~T}$ & $11.2 \pm 1.7$ & $6.7 \pm 1.2$ & $4.9 \pm 0.8$ & $6.4 \pm 0.7$ & Phase III, Total \\
\hline $98081315 U$ & $4.1 \pm 2.2$ & $-1.1 \pm 0.8$ & $0.5 \pm 0.6$ & $0.1 \pm 0.5$ & Phase III, Unattached \\
\hline $98081316 \mathrm{~T}$ & $9.8 \pm 1.5$ & $3.9 \pm 1.0$ & $4.2 \pm 0.7$ & $4.6 \pm 0.6$ & Phase III, Total \\
\hline $98081316 \mathrm{U}$ & $2.7 \pm 1.7$ & $-2.4 \pm 1.2$ & $1.7 \pm 1.0$ & $-0.3 \pm 0.7$ & Phase III, Unattached \\
\hline $98081317 \mathrm{~T}$ & $5.6 \pm 1.2$ & $3.8 \pm 0.8$ & $2.3 \pm 0.6$ & $3.4 \pm 0.5$ & Phase III, Total \\
\hline $98081317 \mathrm{U}$ & $4.2 \pm 2.2$ & $1.9 \pm 1.4$ & $-0.5 \pm 0.3$ & $1.2 \pm 0.7$ & Phase III, Unattached \\
\hline $98081409 \mathrm{~T}$ & $96.1 \pm 4.7$ & $26.1 \pm 2.5$ & $19.2 \pm 1.7$ & $30.3 \pm 1.5$ & Phase IV, Total \\
\hline $98081409 \mathrm{U}$ & $90.4 \pm 9.5$ & $3.5 \pm 6.6$ & $10.4 \pm 3.3$ & $15.1 \pm 3.7$ & Phase IV, Unattached \\
\hline $98081410 \mathrm{~T}$ & $90.3 \pm 4.5$ & $27.4 \pm 2.5$ & $18.4 \pm 1.7$ & $30.1 \pm 1.5$ & Phase IV, Total \\
\hline $98081410 \mathrm{U}$ & $79.5 \pm 9.1$ & $3.7 \pm 6.7$ & $11.2 \pm 3.4$ & $14.4 \pm 3.7$ & Phase IV, Unattached \\
\hline $98081411 \mathrm{~T}$ & $93.9 \pm 4.6$ & $27.7 \pm 2.5$ & $20.5 \pm 1.8$ & $31.4 \pm 1.5$ & Phase IV, Total \\
\hline $98081411 \mathrm{U}$ & $82.1 \pm 9.3$ & $16.2 \pm 7.1$ & $6.4 \pm 3.2$ & $19.1 \pm 3.9$ & Phase IV, Unattached \\
\hline $98081412 \mathrm{~T}$ & $110.0 \pm 5.0$ & $29.9 \pm 2.6$ & $19.0 \pm 1.8$ & $33.6 \pm 1.5$ & Phase IV, Total \\
\hline $98081412 \mathrm{U}$ & $94.5 \pm 9.9$ & $24.0 \pm 7.9$ & $6.5 \pm 3.5$ & $24.3 \pm 4.3$ & Phase IV, Unattached \\
\hline
\end{tabular}

conditions. Since radon progeny concentrations were fractionally measured with grab sampling, the unattached fraction(hereafter called $f_{p}$ ) could be obtained. Table 2 shows results of individual radon progeny concentrations and EERC with grab sampling and measurement.

Using all the results, the physical parameters related to dose assessment were evaluated. Table 3 summarizes the physical parameters on dose assessment under various environmental conditions. The activity median diameter (AMD) of radon progeny was computed with the GMD, GSD of ambient aerosols and the attachment theory. The computation process is described by Tokonami ${ }^{14)}$. Since the air-conditioning in this room induced internal air circulation through a pre-filter, it reduced the equilibrium factor (hereafter called $\mathrm{F}$ ). Compared Phase I to II, the F differs by the factor of 2 . When evaluating the $f_{p}$, there was a minor difference between the two phases. The $F$ and $f_{p}$ on Phase III were estimated to be 0.39 and 0.13 , respectively. Note that the radon concentration cannot be accepted as the representative value on Phase III. Because the observation period on Phase III was short and the environmental condition was not stable. Since it is considered that the continuously passive measurement of radon concentration with the AlphaGUARD provides the data with some time delay, in addition, it is difficult to determine the $\mathrm{F}$ using such data and their corresponding progeny concentrations as far 
Table 3 Physical parameters on dose under assessment under various environmental conditions

\begin{tabular}{cccccc}
\hline Phase & F & $\mathrm{f}_{\mathrm{p}}$ & GMD $(\mathrm{nm})$ & GSD & Computed AMD (nm) \\
\hline I & 0.21 & 0.13 & 126 & 1.6 & 196 \\
II & 0.54 & 0.10 & 135 & 1.6 & 210 \\
III & $(0.39)$ & 0.13 & 110 & 1.7 & 193 \\
IV & 0.22 & 0.56 & 112 & 1.7 & 197 \\
\hline
\end{tabular}

Table 4 Dose conversion factors due to radon progeny inhalation under various environmental conditions

\begin{tabular}{ccc}
\hline Phase & Breathing rate $1.2 \mathrm{~m}^{3} \mathrm{~h}^{-1}$ & Breathing rate $0.78 \mathrm{~m}^{3} \mathrm{~h}^{-1}$ \\
\hline I & 22.3 & 15.9 \\
II & 19.9 & 14.3 \\
III & 24.2 & 16.9 \\
IV & 55.5 & 36.5 \\
\hline & & unit: $\mathrm{mSv}$ WLM $^{-1}$
\end{tabular}

The DCF was calculated with the ICRP Publication 66 respiratory tract model.

as its instrument performance is not well understood. Therefore, the F on Phase III was used as the tentative value and was given in parenthesis. The air cleaner drastically enhanced the $\mathrm{f}_{\mathrm{p}}$ up to $56 \%$, whereas the $\mathrm{F}$ was not so small. The reason was considered as follows: Since more ultrafine progeny of ${ }^{214} \mathrm{~Pb}$ and ${ }^{214} \mathrm{Bi}$ were still left in air than those on Phase I, both total and unattached progeny concentration were enhanced. Consequently, this fact induced a high value of the F. As long as the computed AMD was seen, they were estimated to be around $200 \mathrm{~nm}$ throughout the entire conditions. With these values as well as individual radon progeny concentration ratios obtained from Table 2, the DCF was calculated using the ICRP Publication 66 respiratory tract model (computer code : LUDEP 2.0 ${ }^{15)}$ and was relatively compared among various conditions as shown in Table 4 . Breathing rates were set at $1.2 \mathrm{~m}^{3} \mathrm{~h}^{-1}$ for occupational exposure and 0.78 $\mathrm{m}^{3} \mathrm{~h}^{-1}$ for environmental exposure, respectively. When comparing the DCF from the viewpoint of the breathing rate, it is natural that a high breathing rate induces a high dose. This table describes air-conditioning and ventilation makes the DCF high. The DCF ranged from 14.3 to $55.5 \mathrm{mSv} \mathrm{WLM}^{-1}$ in the present work though those of $13.7 \mathrm{mSv} \mathrm{WLM}^{-1}$ in mines and $14.3 \mathrm{mSv} \mathrm{WLM}^{-1}$ at homes were given as the reference value in another paper ${ }^{16)}$. The present study has also revealed that the DCF varies widely with environmental conditions ${ }^{17)}{ }^{18}$ ). When determining the DCF, the most effective human activity was a use of the air cleaner. It is obvious that ventilation is more effective for dose mitigation. In addition, even a single use of the airconditioner can reduce the dose ${ }^{19)}$. In the present study, the effectiveness of the air cleaner could not be well explained from the viewpoint of dose mitigation though Hopke et al. have shown the effectiveness on several types of air cleaner ${ }^{20)}$. The air cleaner appears to be more effective at removing particles than unattached progeny leading to increased 
unattached fractions of the potential alpha energy concentration. An effect for dose mitigation seems to be somewhat offset. Further studies will be required to clarify the effectiveness.

\section{Conclusions}

From the viewpoint of the dose assessment due to radon progeny inhalation, its associated physical parameters were measured in an indoor environment. The DCF was determined with the ICRP Publication 66 respiratory tract model. It was found that air-conditioning was effective for dose mitigation as well as the ventilation. On the other hand, effectiveness of the air cleaner could not be well explained because the unattached fraction has increased and subsequently the DCF has also increased. The present study has eventually revealed the DCF varies widely with environmental conditions given by human activities and the most sensitive parameter is the $\mathrm{f}_{\mathrm{p}}$.

\section{References}

1) United Nations: "Sources and Effects of Ionizing Radiation. United Nations Scientific Committee on the Effects of Atomic Radiation, 2000 Report to the General Assembly, with Annexes", United Nations publication Sales No. E.00.IX.3, New York (2002)

2) International Commission on Radiological Protection: "Human Respiratory Tract Model for Radiological Protection", Annuals of the ICRP 24 (1-3). ICRP Publication 66, Pergamon Press, Oxford (1994)

3) Birchall, A. and James, A. C.: Uncertainty analysis of the effective dose per unit exposure from radon progeny and implications for ICRP risk-weighting factors, Radiat. Prot. Dosim., 53, 133-140(1994)

4) Zock, C., Porstendörfer, J., and Reineking, A.: The influence of biological and aerosol parameters of inhaled short-lived radon decay products on human lung dose, Radiat. Prot. Dosim., 63, 197-206 (1996)

5) Marsh, J. W. and Birchall, A.: Sensitivity analysis of the weighted equivalent lung dose per unit exposure from radon progeny, Radiat. Prot. Dosim., 87, 167-178(2000)

6) Martz, D. E., Holleman, D. F., MacCurdy, D. E. and Schiager, K. J.: Analysis of atmospheric concentrations of $\mathrm{RaA}, \mathrm{RaB}$ and $\mathrm{RaC}$ by alpha spectroscopy, Health Phys., 17, 131-138(1969)

7) Tokonami, S.:Determination of the diffusion coefficient of unattached radon progeny with a graded screen array at the EML radon/aerosol chamber, Radiat. Prot. Dosim., 81, 285-290 (1999)

8) Kurosawa, R., Iimoto, T., Ichiji, T. and Tokonami, $\mathrm{S}$. : Practical interpretative method for indicating values of the continuous sampling and gross counting PAEC monitor, Radioisotopes, 45, 14-19 (1996)

9) Yamada, Y., Tokonami, S., Fukutsu, K. and Shimo, M.: Improvement of the SDB/CNC aerosol sizing system for fast measurement at field, Radiat. Prot. Dosim., 88, 329-334 (2000)

10) Sanada, T., Fujimoto, K., Miyano, K., Doi, M., Tokonami, S., Uesugi, M. and Takata, Y.: Measurement of nationwide indoor Rn concentration in Japan, J. Environ. Radioact., 45, 129-137 (1999)

11) Tokonami, S., Yang, M., Yonehara, H. and Yamada, Y.: A simple, discriminative measurement technique for radon and thoron concentrations with a single scintillation cell, Rev. Sci. Instrum., 73, 69-72 (2002)

12) Tokonami, S., Yonehara, H., Yang, M., Furukawa, M. and Yamada, Y.:Exhalation rate measurements of thoron and radon from building materials using scintillation cells, “Proc. $5^{\text {th }}$ Conference on High Levels of Natural Radiation and Radon Areas, Radiation Dose and Health Effects", pp. 665-669(2002)

13) Tokonami, S., Iimoto, T. and Kurosawa, R.: Continuous measurement of the equilibrium factor $F$ and the unattached fraction $f_{p}$ of radon progeny in the environment, Environ. Int., 22, 


\section{S 611-S 616(1996)}

14) Tokonami, S.:Experimental verification of the attachment theory of radon progeny onto ambient aerosols, Health Phys., 78, 74-79 (2000)

15） Jarvis, N. S., Birchall, A., James, A. C., Bailey, M. R. and Dorrian, M. D.:LUDEP 2.0, personal computer program for calculating internal doses using the ICRP Publication 66 respiratory tract model, NRPB-SR287, Chilton : National Radiological Protection Board (1996)

16) Ishikawa, T., Tokonami, S., Yonehara, H., Fukutsu, K. and Yamada, Y.: Effects of activity size distribution on dose conversion factor for radon progeny, J. Health Phys., 36, 329-338 (2001)

17) Solomon, S. B. : A radon progeny sampler for the determination of effective dose, Radiat. Prot. Dosim, 72, 31-42 (1997)

18) Porstendörfer, J. and Reineking, A.: Radon: Characteristics in air and dose conversion factors, Health Phys., 76, 300-305 (1999)

19) Yu, K. N., Guan, Z. J., Liu, X. W., Young, E. C. M., Stokes, M. J. and Cheung, T.: Mitigation of indoor radon hazard by air conditioning, J. Radiol. Prot., 15, 67-71 (1995)

20) Hopke, P. K., Montassier, N. and Wasiolek, P.: Evaluation of the effectiveness of several air cleaners for reducing the hazard from indoor radon progeny, Aerosol Sci. Technol., 19, 268-278 (1993) 